https://helda.helsinki.fi

\title{
Long-term recovery from apraxia and its relation to severe apraxic-aphasic disorder in left hemisphere stroke - a systematic review
}

\section{Lemmetyinen, Sanna}

2020-06-02

Lemmetyinen , S , Hokkanen , L \& Klippi , A 2020 , ' Long-term recovery from apraxia and its relation to severe apraxic-aphasic disorder in left hemisphere stroke - a systematic review ' , Aphasiology , vol. 34 , no. 6 , pp. 735-756 . https://doi.org/10.1080/02687038.2019.1636932

http://hdl.handle.net/10138/317190

https://doi.org/10.1080/02687038.2019.1636932

acceptedVersion

Downloaded from Helda, University of Helsinki institutional repository.

This is an electronic reprint of the original article.

This reprint may differ from the original in pagination and typographic detail.

Please cite the original version. 


\section{Long-term recovery from apraxia and its relation to severe apraxic-}

\section{aphasic disorder in left hemisphere stroke - a systematic review}

Sanna Lemmetyinen ${ }^{1,2}$, Laura Hokkanen ${ }^{2}$ \& Anu Klippi ${ }^{2}$

1: Siun sote Siilainen rehabilitation center, Neurological rehabilitation, Joensuu, Finland; 2:

Department of psychology and logopedics, Faculty of Medicine, University of Helsinki, Finland

sanna.lemmetyinen@helsinki.fi 


\title{
Long-term recovery from apraxia and its relation to severe apraxic-
}

\section{aphasic disorder in left hemisphere stroke - a systematic review}

\begin{abstract}
Background and Purpose: Left hemisphere stroke often causes a severe communication disorder that is usually attributed to aphasia. While aphasia refers to linguistic problems, communication is also accomplished by voluntarily articulate and gestural movements, which may be compromised due to apraxia. Along with aphasia, apraxia is a common disorder in left hemisphere stroke, which in severe cases can limit the use of verbal and nonverbal communication methods. The discussion about apraxia from a communicative perspective is still scarce, although the disorder is regularly experienced among left hemisphere stroke patients with aphasia. The rehabilitation of the disorder in severe apraxia-aphasia is challenging and recovery is slow. The purpose of this study is to provide an overview of the research on long-term recovery from apraxia, and to discuss the meaning of these findings in observing recovery of communication abilities in a person with a severe apraxia-aphasia. The search was not restricted to any specific type of apraxia, as this review assumes that communication may be influenced by apraxia in its different manifestations.
\end{abstract}

Method: The review is based on a systematic literature search, which includes Englishlanguage studies retrieved from the databases of Ovid Medline, Psycinfo, and Scopus.

Results: Seven long-term follow-up studies of apraxia were found; one case study of apraxia of speech (AOS), four group studies of ideomotor apraxia (IMA), one case study of IMA (and aphasia), and one group study of limb apraxia.

Conclusion: The reviewed group studies of patients with left hemisphere stroke indicate that apraxia is a persistent disorder, but the steepest recovery occurs within the first few months post-stroke. Imitation skills and actions involving real-tool use in activities of daily functions shows the best recovery. Real-tool use also continues to improve longer, while recovery of gesturing after verbal command may not show clear signs of recovery in the chronic stage post-stroke. There is some evidence that the pace of recovery from oral apraxia and limb apraxia is comparable, and recovery from apraxia and aphasia would not correlate. Some of the studies used only imitation to assess changes in gesturing, which cannot be regarded as an ecologically valid measure to compare gesturing in natural communicative situations or even 
gesturing after verbal command. Finally, no follow-up studies were found that would have discussed apraxia from a communicative perspective. Overall, the field is lacking research on long-term follow-up of patients with apraxic-aphasic disorder

Keywords: stroke, apraxia, aphasia, recovery, communication

\section{Introduction}

Aphasia is an acquired language disorder with linguistic problems in comprehending and producing speech and with difficulties in reading and writing (e.g. LaPointe, 2005). Apraxia, on the other hand, is a disorder where a person has difficulties in producing voluntary, learned, goal-directed movements that cannot be explained by physical problems or difficulties with understanding, attention, or motivation (Rothi \& Heilman, 1997; Goldenberg 2013). It is difficult to distinguish between apraxia and aphasia, as it is often challenging to recognize whether the difficulties of speech are due to apraxic articulative problems or aphasic paraphasia (e.g. Ballard, Wambaugh, Duffy, Layfield, Maas, Mauszycki \& McNeile, 2015). Furthermore, obeying given instructions may be due to problems of understanding because of aphasia, or due to difficulties in performing voluntary bodily actions because of apraxia (see also Wertz, LaPointe \& Rosenbek, 1991; EtcharryBouyx, Le Gall \& Osiurak, 2017). In this study, we refer to apraxic-aphasia as a disorder where a person after left hemisphere stroke has not only a very limited or absent speech output but also profoundly limited skills of using other methods of communication, such as gestures, drawing, writing, or use of external aids (e.g. pictures). Therefore augmentative and alternative communication methods (AAC) are often offered as means to compensate absent speech to help a person to express oneself and participate socially (e.g. Elman, 2005). Yet, these methods may be extremely challenging to use for a person with a severe apraxic-aphasic disorder (see also Hogrefe et al. 2011).

Aphasia and apraxia, with its different manifestations, are usually caused by lesions in the left hemisphere of the brain (e.g. Graff-Radford, Jones, Strand, Rabinstein, Duffy \& Josephs, 
2014; Weiss, Ubben, Kaesberg, Kalbe, Kessler, Liebig \& Fink, 2016; Etcharry-Bouyx et al., 2017). About two thirds of left hemisphere stroke patients suffer from some level of aphasia and about half of them are also estimated to demonstrate apractic behaviour. Apraxia can be an independent disorder, but apraxia without aphasia is still rare (e.g. Graff-Radford et al., 2014; Weiss et al., 2016). However, aphasia without apraxia is somewhat more common as shown in a study by Weiss et al. (2016) on 50 subacute left hemisphere patients. In this study, 74\% had aphasia and (limb) apraxia, 24\% had aphasia without apraxia, and only $2.4 \%$ had apraxia without aphasia.

\section{Types of apraxia}

Apraxia has several different manifestations and there is currently no consensus on terminology. Classification depends on perspective. This depends on whether apraxia is considered as a disturbance of a certain body function, involves a certain type of action, or involves a disturbance of a particular cognitive function (e.g. see reviews by Etcharry-Bouyx et al., 2017; Baumard, Osiurak, Lesourd \& Le Gall, 2014). Terms such as limb apraxia, apraxia of speech, and oral (or buccofacial or facial) apraxia refer to a body function. Apraxia of tool use and gestural apraxia refer to an action, and ideomotor apraxia and ideational apraxia refer to a cognitive function. These terms are regularly used in literature and in the studies that will be presented here. The most typical manifestations of apraxia are clarified next.

Apraxia of speech (AOS), a difficulty to produce volitional speech movements, can appear in different levels of severity, ranging from mild speech impairment to a total loss of speech (GraffRadford et al., 2014; Ballard et al., 2015; Wertz et al. 1991). Diagnosing AOS is often challenging due to co-occurrence with aphasia, which both cause problems in speech. AOS can also (albeit rarely) appear as a pure form, where any other type of apraxia or language or cognitive impairments measured in clinical settings are absent (Polanowska \& Pietrzyk-Krawczyk, 2016; Patiral et al., 2017). When speech exists, AOS is characterized by abnormalities in articulation and prosody, slow speech rate, pauses, difficulties in controlling the rhythm of speech, abnormalities in word stress, 
groping articulation, distortions, substitutions, and omissions of speech sounds. However, automatic overlearned speech (such as a list of numbers or weekdays) is easier to produce. Speech might also be produced correctly in spontaneous situations, which lack external voluntary guidance (Patiral, Ciniglia, Calvert \& Altschuler, 2017).

Contrary to AOS, oral apraxia (OA) refers to a disorder of voluntary nonspeech oral and facial movements (eg. Rothi \& Heilman, 1997, Wertz et al. 1991). The relationship between AOS and OA is unclear, but more severe OA has shown to correlate with more severe AOS (Mimura, Fitzpatrick \& Albert, 1996; Whiteside, Dyson, Cowell \& Varley, 2015). Yet, although AOS and OA usually co-occur, they can also appear alone.

According to the literature, limb apraxia generally refers to a disorder that causes disturbances of actions of tool use, gesturing, or both. However, the cognitive demands of these two actions differ from one another; tool use involves a concrete object in its natural context and gesturing relies on mental images of an action (see review by Goldenberg, 2017). Different manifestations of limb apraxia are described below.

In ideomotor apraxia (IMA) the manipulation of an object or a tool is clumsy and prone to errors and a movement of a specific gesture is unclear, because of the difficulties to find the way how skilled movements are to be executed (Rothi \& Heilman, 1997; Vanbellingen \& Bolthalter, 2011). In ideational apraxia, instead, the knowledge of what to do with an object is lost, as in a situation where a person does not know what to do with a toothbrush or what are the necessary steps and appropriate items needed to clean one's teeth.

Gestural apraxia manifests as clumsy, unclear, or even unrecognizable gestures (e.g. Vanbellingen \& Bolthalter, 2011). Hand movements, as a dictated task, may involve spatial errors, such as waving in the wrong direction or placing a hand on one's chin instead of on the ear. A gesture might also be substituted with other gestures unsuitable for the situation, the gesture may be a perseveration of a previous one, or the gesture is not initiated at all. Even though a person with 
apraxia cannot produce accurate gestures in voluntary goal-directed situations, simple gestures, like waving, may occur correctly in spontaneous communicative situations that have not involved external guidance (e.g. Rose \& Douglas, 2003). Gestural apraxia is typically assessed by tasks of pantomiming, which can be intransitive or transitive in nature (e.g. Vanbellingen \& Bolthalter, 2011). Intransitive gestures are meaningful simple actions that are used to replace or clarify speech and do not involve an imagined object (e.g. greetings or beckoning). Transitive gestures are pantomiming without an object and are often used in situations such as where talking is not allowed or the surrounding environment is too noisy. An example of a transitive gesture could be mimicking of making a phone call without a real phone in hand.

In contrast, apraxia of tool use manifests as clumsy, slow, and incorrect handling of a tool (see review by Etcharry-Bouyx et al., 2017). Hand movements chosen according to an object might be incorrect in orientation, speed, or grasp. Apraxia can cause difficulties in performing even simple tasks with an object, or problems may occur in more complicated tasks with several tools and object-related choices (see Baumard et al., 2014). Apraxia of tool use influences activities of daily living (ADL), such as grooming, dressing, and cooking (Vanbellingen \& Bohlhalter, 2011, also e.g. Etcharry-Bouyx et al., 2017).

Overall, a presence of (limb) apraxia has been found to be one of the deficits reducing functional independence considering discharge from hospital after stroke (Gianquinto, Buzzelli, Di Francesco, Lottarini, Montenero, Tonin \& Nolfe, 1999). Limb apraxia has also been indicated to be one of the significant obstacles for returning to work after stroke (Saeki, Ogata, Okubo, Takahashi \& Hoshuyama, 1995). While limb apraxia and its relation to communication abilities is yet little discussed, limb apraxia may also get little attention when assessing activities of daily functions (ADL), even though it has been shown to have an effect on one's basic daily activities, such as mealtime behaviour (Foundas, Macauley, Raymer, Maher, Heilman \& Rothi, 1995). 


\section{Aims of the study}

The aim of this article is to clarify what has been studied on the long-term recovery from apraxia and, based on the retrieved studies, to discuss the meaning of recovery from apraxia to communication abilities of a person with severe apraxic-aphasic disorder. The search was not restricted to any specific type of apraxia, as it was assumed that communication may be influenced by apraxia in its different manifestations from speech to gesturing and using tools as a communicative aid.

Apraxia of speech has long been considered as a communication barrier (Wertz et al., 1991). AOS is acknowledged in speech therapy, where it is necessary to differentiate from dysarthria and aphasia (e.g. Patiral et al., 2017; Polanowska \& Pietrzyk-Krawczyk, 2016) to determine the most effective treatment (see e.g. Ballard et al., 2015). The clinical implications of oral apraxia from a communicative point of view are less clear. Limb apraxia is considered as a functional problem in activities of daily functions, and thus discussion about its non-verbal influence on communication is fairly limited. Clinicians may encounter the combined effect of apraxia and aphasia on the person's abilities to gesture by hand movements (e.g. Goldenberg \& Randerath, 2015; Borod, Fitzpatrick, Helm-Estabrooks \& Goodglass, 1989) and, for example, to use a pen as a tool (e.g. O'Reilly, 2016; Otsuki, Soma, Arai, Otsuka \& Tsuji, 1999). Assessment and rehabilitation of limb apraxia is often performed within occupational therapy and may not be consistently noted in speech therapy even though it clearly also has an influence on communication abilities (also e.g. Goldenberg, 2017; Vanbellingen, T. \& Bohlhalter, 2011).

\section{Method}

This study applied a scoping review method that enables a literature search from a broader perspective and without one specific study question (see Arksey \& O'Malley, 2005). The method 
proceeds through several steps of a systematic search, namely identifying the research questions and defining key words for literature search; identifying relevant studies without limitation of quality; selection of studies for full text review; sorting the material; and summarizing and reporting the results. Ignoring the quality of studies as an inclusion criterion means that a scoping review does not reject studies provided that the subject is relevant to the topic. However, possible defects and limitations will still be discussed.

Although the study question of this review is limited to recovery of apraxia after left hemisphere stroke, the original search was broader and used multi-dimensional search words. The search was performed on 18.12.2017 using the databases of Ovid Medline, Psycinfo, and Scopus. The search had no time limit, which meant that the search had the possibility to produce all the studies that were freely accessible by the mentioned date above. The keywords used were apraxia AND stroke, which were linked to following keywords; gesture, pantomime, pointing, visuomotor, head move, recovery, rehab*, lesion, follow-up, communication, writing, painting, drawing, understanding, comprehension OR evaluation. To verify that the keyword stroke included both haemorrhage and infarct, the keywords haemorrhage OR infarct were added to the same search history on 4.12.2018. This search did not produce new references.

Figure 1 summarizes the search process. The initial search produced 1565 results. After removing duplicates, 805 references remained. Based on screening the titles and the abstracts, references were rejected if the article was not published in English, if apraxia (or praxis) was not mentioned in the title or in the abstract, or if apraxia was not caused by a stroke. After this step 357 references remained. For the purposes of the present study, all abstracts that were clearly related to the recovery of apraxia were chosen for a full text review. The selection also included some abstracts that provided background for the subject of apraxia and its influence on behaviour; this included AOS, gestural apraxia, and apraxia in ADL. A total of 56 articles were found. Nineteen could not be found from e-resources and thus excluded (one was a book), except two that had direct 
relevance to this study. They were obtained elsewhere; one study (Basso, Capitani, Della Sala \& Spinnler, 1987) was obtained from the library at the University of Helsinki and the other (Mimura, Fitzpatrick \& Albert, 1996) was requested and received from the authors. The reference lists of the remaining 39 articles were reviewed. Based on the previously mentioned inclusion criteria, an additional 33 relevant articles were identified. One of these was a study by Foundas, Raymer, Maher, Gonzales-Rothi \& Heilman (1993), mentioned in the paper by Basso, Burgio, Paulin \& Prandoni (2000), which seemed to involve long-term follow up on the recovery of ideomotor apraxia. However, the abstract of this study could not be located. Furthermore, an expert in the field suggested one more study (Schnider, Landis \& Rösler, 1991) for inclusion that was not found through the original search or reference lists. Thus, altogether 72 articles were reviewed. Of these, 49 articles did not involve the actual subject of recovery of apraxia, which left 23 articles for a final full text review. This included altogether 16 articles where apraxia was not a focus of the study, and articles that were a summary or a chapter of a book. Finally, this search found seven studies that focused on long-term recovery of apraxia in left hemisphere stroke.

(Figure 1 here)

\section{Results}

The seven studies on recovery of apraxia retrieved through the literature search are presented here and summarized in Table 1.

A 1-year follow-up case study by Polanowska and Pietrzyk-Krawczyk (2016) examined the recovery of apraxia of speech in a man with a left ischaemic cerebral vascular accident (CVA). He was diagnosed as having a pure AOS. One-week post-stroke he was already able to produce voice, but his articulation movements were slow and his speech included distortions, omissions, and groping movements. Dysarthria and signs of oral apraxia or limb apraxia were absent. Tests revealed unimpaired linguistic skills. After the first examination, the patient received a 3-week 
period of speech therapy (total 15 sessions; 30 minutes per session). At a follow-up examination at 1 month, his voice quality was normal and he still spoke slowly with pauses. However, speech errors occurred mainly in longer or more complex words. After 3 months, the only clear abnormality was in speech prosody as he had a tendency to divide some words into syllables, which seemed to function as a compensatory strategy. At 1-year post-onset his speech still had some unordinary prosody, sounding like the speech of non-native speaker.

A case study by Schnider et.al (1991) followed the course of ideomotor and oral apraxia and aphasia over a 5-month period. The study involved a woman with haemorrhage in the posterior part of the left thalamus and internal capsule. The injury caused right hemiplegia, severe IMA, and oral apraxia and aphasia. During the first days she was unable to initiate speech, she could obey only short verbal commands, her reading comprehension seemed poor, and she could not write or draw. Performing meaningful gestures and oral movements was unclear. At day 11 she was already able to speak simple sentences spontaneously and to copy simple drawings and writing. At this time she started to regain the ability to perform oral movements and simple pantomimes on request. IMA and oral apraxia disappeared by 3 weeks post-stroke. However, the tendency to use a body part as an object in pantomime tasks remained even at the 5-month follow up. Over the next 5 months the patient's speech became fluent without any paraphasias and writing was errorless. The study did not include a discussion about the effect of recovery from apraxia on communication abilities.

Mimura et al. (1996) examined the long-term recovery of limb apraxia and buccofacial apraxia up to nearly 7 years post-stroke. The aim of this study was also to examine if recovery from apraxia and aphasia are associated. The study included 15 participants with left hemisphere stroke (type of stroke was not mentioned). The language evaluation revealed that seven participants had fluent aphasia, seven had non-fluent aphasia, and one had mixed symptoms. More specific information about the symptoms of aphasia were not provided. None of the patients received speech therapy 1 year post-stroke. Examinations were performed at a mean of 4.5 months and again at a 
mean of 81.6 months post-stroke. Improvement was found to be significant in both measured apraxia tasks of limb and buccofacial movements, both by verbal command and imitation. Imitation, however, showed better improvement in both apraxia types. Regarding limb gestures, five patients remained mildly and one remained moderately apraxic. Severity of limb apraxia at the first examination correlated with more severe limb apraxia later, but the correlation was not as clear in buccofacial apraxia where recovery varied. The severity of buccofacial apraxia also correlated with the severity of non-fluent aphasia. Furthermore, performances in limb praxis tasks showed no difference between patients with fluent and non-fluent aphasia, while performances in buccofacial movements recovered better in patients with non-fluent aphasia. The results also showed that language measures did not correlate with recovery from apraxia. The authors suggested that apraxia and aphasia are related but their recovery process differs. The study did not include a discussion about the effect of recovery from apraxia on communication abilities.

Stamenova, Black and Roy (2011) examined spontaneous recovery of limb apraxia with a mean follow-up time of 2 years. The study included 37 participants either with left or right CVA (type of stroke was not mentioned). Apraxia was not an explicit inclusion criterion as the aim was to examine how performance in examination tasks of gesture production or identification (conceptual knowledge of actions and tools) changes over time in CVA generally. Examinations were performed either in acute-subacute stage post-stroke or in chronic stage post-stroke. The study thus also compared recovery between these two stages of post-onset but did not discuss whether the site of a lesion (left or right) had an effect on symptoms or recovery of apraxia. Altogether 25 participants were impaired in object use (to demonstrate the use of a real tool) and also showed significant recovery in the chronic stage post-stroke. Twenty-three participants were impaired in imitation and imitation also showed significant recovery over time. Twenty-three participants were impaired in a task of pantomime by verbal command or by picture; some recovery in pantomime was observed in the acute-subacute stage but less clearly in the chronic stage post-stroke. According 
to the authors, continuing recovery in the chronic stage in tasks of imitation and real-tool use may be due to natural practice in everyday situations, while pantomime by command or from a picture may not be practiced without a specific therapy. The study did not include a discussion about the effect of recovery from apraxia on communication abilities.

A study by Basso et.al (2000) followed the recovery of verbal comprehension, non-verbal abstract reasoning, and ideomotor and oral apraxia by tasks of imitation until approximately 2 years post-stroke. The study included 44 left hemisphere (type of stroke was not mentioned) participants. The follow-up included three examinations; the first at a mean of 1.6 months, the second at a mean of 9.4 months, and the third at a mean of 27.9 months post-stroke. The study only used the tasks of imitation (hand and oral movements) to exclude the possible interference of aphasia with the reception of verbally given commands. Although language comprehension and non-verbal reasoning were also measured, the study did not specify how many participants had aphasia. The results showed a significant recovery of all measured tests between the first and second examination in all tested patients. Recovery of ideomotor or oral apraxia was no longer significant by the third examination. The 18 participants that were still clearly apractic in the second examination showed no further recovery in the third examination. At the same time, language and non-verbal reasoning continued to show significant improvement until the third examination. All participants except one received rehabilitation at least until the second examination. However, the nature and full duration of rehabilitation was not given in detail. Even though participants underwent language examinations, the study did not discuss the possible relation of apraxia and aphasia.

An earlier study by Basso et al. (1987) followed the course of ideomotor apraxia of 26 participants with a left cerebrovascular accident (type of stroke was not mentioned) and IMA. The first examination was performed 15 to 30 days after the stroke and the second at least 5 months after the stroke. Those who were still apraxic at the second examination were tested a third time some months later (the exact time of the third examination is unclear). Apraxia was tested with 
buccofacial and arm movements after imitation. Language and non-verbal reasoning were also examined. All but two of the participants were found to have aphasia; 13 were classified as nonfluent, 10 fluent, and two could not be classified. All participants showed significant improvement in ideomotor apraxia scores in the second examination 5 months post-stroke. Only 13 participants were found to be apraxic. In the third examination, five participants were still apraxic. The results indicated that improvement in tests of IMA and oral apraxia correlated more than IMA and other tests (the article did not reveal the scores of other tests besides IMA). The five participants that remained apraxic all had lesions in temporo-parieto-occipital areas. The authors concluded that a lesion in this area may have prevented recovery from IMA and that recovery in posterior lesions overall seem to be poorer than in anterior lesions. The study also included participants with bilateral focal lesions and the results suggested that another lesion in the right hemisphere did not affect recovery from IMA. The study did not include a discussion about the effect of recovery from apraxia on communication abilities even though aphasia was examined at least at the first examination.

Donkervoort, Dekker and Deelman (2006) studied the course of apraxia and its relationship to activities of daily functions within a 5-month follow-up period. Assessment of apraxia consisted of imitation of gestures and use of objects. The study included 108 participants with left CVA (infarction 85 , haemorrhage 15 , other/unknown 8). The data was collected from a randomized clinical trial that compared occupational strategy training and occupational usual treatment with a rehabilitation duration of 8 weeks. The article did not provide more specific information on the given rehabilitation. The aim of the study was not to examine the effects of the treatment but to explore the course of apraxia during follow up. While apraxia tests showed significant improvement in both examinations at 8 and 20 weeks after baseline, about $90 \%$ of participants were still considered apraxic by the end of follow up. Apraxia scores improved more in patients with more severe apraxia. Nevertheless, more severe apraxia correlated with less improvement in ADL 
observations scores at 8 weeks. However, at the second examination this difference was no longer apparent. Higher age correlated with less improvement in ADL observations in both examinations. Overall, the authors concluded that participants demonstrated more improvement in ADL functioning than in apraxia tests. The authors suggested that the participants may have learned to compensate for their difficulties in daily life even though apraxia was still present. The study did not include a discussion about the effect of recovery from apraxia on communication abilities.

(Table 1 here)

\section{Discussion}

The aim of this study was to summarize existing research about the long-term recovery from apraxia and its possible relation to communication abilities in cases with a severe apraxic-aphasic disorder. The search was not restricted to any specific type of apraxia, as this study is left open to the possibility, that apraxia of any type may have an influence on communication. The findings from a communicative point of view turned out to be limited, as most of the studies focused mainly on limb apraxia with no discussion about the effect of recovery from apraxia on communication abilities. Nevertheless, based on the analysed studies, this discussion section will provide insight about the influence of apraxia on communication in severe aphasia.

In this study, apraxic-aphasic disorder refers to a state where a person after a left hemispheric stroke has lost the ability to speak and lost the ability to compensate speech by supporting communication. In these cases, the combination of aphasia with its linguistic problems and apraxia with its effects to voluntary speech movements and gesturing is extremely disabling disorder in one's everyday life. Knowledge on recovery from apraxia is needed for planning communicative rehabilitation in people with a severe apraxic-aphasic disorder. Clinical experience has shown, that communication abilities in people with aphasia with severe apraxia in speech and 
limb movements often remain highly deficient despite the person's motivation to express oneself appropriately (see also Hogrefe, Ziegler, Weidinger \& Goldenberg, 2011).

After summarizing the search results, specific issues drawn from the studies will be discussed from the communicative point of view.

\section{Summary of search results}

The search covered literature published until the end of the year 2017 and produced 805 references that were screened according to a scoping review method (Arksey \& O'Malley, 2005). The search ultimately produced seven studies published between 1987 and 2016 that described long-term follow up of apraxia. Altogether, the studies differed in terms of methods, transparency of tests, how clearly they revealed the site of the lesions, and how they utilized language measures. For example, two of the studies did not include any linguistic measurements, and only three had some mention about participants language functions. There were also some differences in the definitions of apraxia, such as oral apraxia versus buccofacial apraxia and ideomotor apraxia versus limb apraxia.

The retrieved studies included a 1-year follow-up study on AOS by Polanowska et al. (2016). However, this study did not include limb apraxia or aphasia, as it described a case with "pure" AOS that recovered well within a year. A case study by Schnider et al. (1991) of a patient with left thalamic haemorrhage examined recovery from ideomotor apraxia alongside the course of aphasia, which both recovered well by the 5-month follow up. The group study of Mimura et al. (1997) reported the recovery from apraxia in arm movements and the buccofacial area alongside recovery of linguistic skills. In this nearly 7-year follow-up period, the recovery in praxis was significant, recovery from aphasia and apraxia overall showed no similar recovery processes, but the recovery from buccofacial apraxia correlated with nonfluent aphasia type. Stamenova et al. (2011) presented a group study with an approximate 2-year follow-up period where they studied apraxia and its influence to gesturing by hand and by use of tools. Apraxia of real-tool use was 
found to exhibit the best recovery and pantomime by verbal command and by picture showed poor recovery 3 months post-stroke. This study included participants both with left and right CVA and did not separate the recovery processes between participants which may have distorted the results. While praxic errors of an arm have been shown to co-lateralize with language functions for people with typical left hemisphere cerebral language dominance, for people with atypical right hemisphere dominance this relation is less apparent (Meador, Loring, Lee K, Hughes, Lee G, Nichols \& Heilman, 1999). Studies by Basso et.al. (2000) and Basso et al. (1987) examined recovery from apraxia and its influence on gesturing and oral movements; follow-up varied from 1 month to over 6 months. Basso et al. (2000) noted that scores in language comprehension and nonverbal reasoning continued to improve after 6 months post-stroke, while scores in praxia tasks did not. Donkervoort et al. (2006) studied apraxia and its influence on recovery in daily functions and showed that scores in ADL at 5 months follow up improved more than scores in apraxia tasks.

In terms of recovery from apraxia, the reviewed studies indicate that skills of imitation recover better than skills of pantomiming by verbal command and that recovery in activities of daily functions and tool use recover better than skills in other praxis tasks. Furthermore, compared to milder apraxia, a more severe initial apraxia predicts more severe apraxia later on, even though apraxia at all levels show improvement over time. The best recovery happens in the first months post-stroke. Recovery of gesturing apraxia (pantomime after verbal command) seem to decline after the first months post-stroke. Language skills instead may show improvement long after that. Apraxia and language skills seem not to follow the same recovery processes, although severity of oral apraxia and nonfluent aphasia shows correlation. The main conclusions mentioned here are discussed next in more detail.

\section{Recovery of apraxia of speech and its relation to oral apraxia}

Apraxia of speech is a type of apraxia that is seen as a disturbance of communication and has been recognized in speech and language therapy (see e.g. Wertz et al., 1991). In large left middle cerebral 
artery infarcts, AOS rarely shows recovery and the disorder remains chronic (Trupe, Varma, Gomez, Race, Leigh, Hillis \& Gottesman, 2013). More specifically, recovery seems to be poor if the lesion is in the area of Broadmann 44 or 45 (in Broca's area). Several treatment studies have been performed of AOS (see e.g. Ballard et al., 2015), but this search retrieved only one long-term study about recovery of AOS, a case study by Polanowska et al. (2016), where the recovery from pure AOS was successful. No generalizing conclusions can be made based on one case study.

One reason for the lack of a follow-up studies of AOS may be that its recognition is difficult, as it rarely occurs alone without aphasia or other cognitive impairments (Patiral et al., 2017; Polanowska \& Pietrzyk-Krawczyk, 2016). An issue to note is that as in most cases AOS is combined with aphasia, it can be presumed that some studies that examined recovery of severe aphasia and its speech and language problems might very well have involved participants with severe AOS. Accordingly, apraxia in these studies may not be recognized, assessed, or mentioned.

In this search, a case study by Polanowska et al. (2016) did not detect OA, as AOS type was pure. Besides this, only the study by Mimura et al. (1996) had some discussion about OA and speech as they noticed the correlation of severity and recovery of OA and nonfluent aphasia, but not with fluent aphasia. A definition of nonfluent aphasia can be prescribed as halting speech output with difficulties in word finding and sound production and nonfluent aphasia often includes symptoms of AOS (e.g. Wertz et al., 1991). Thus, the results by Mimura et al. may implicate that a presence of OA can predict a presence of AOS. Indeed, the severity of OA was linked to severity of AOS in a study by Whiteside et al. (2015).

It may be difficult to evaluate a possible meaning of oral apraxia to communication. OA (or facial apraxia) plays a role in voluntary oral and facial expressions (e.g. Rothi \& Heilman, 1997; Wertz et al., 1991) which is one important way to convey messages (e.g. Goldenberg, 2013). Nevertheless, facial expressions are often non-voluntary reactions in interaction with others, comparable to certain type of gestures that can be automatic or unconscious. Practise has shown (by 
the authors) that people with a severe apraxic-aphasic disorder may produce informative spontaneous facial expressions in natural settings even though their production is difficult after command. In line with this, people with limb apraxia may use meaningful gestures in natural settings contrary to clinical settings (Rose \& Douglas, 2003). Yet, the existence of limb apraxia has shown to reduce a comprehensiveness even of spontaneous gestures (Hogrefe et al. 2011; Vanbellingen \& Bolthalter, 2011), but there seem to be a lack of studies that would have examined whether existence of OA reduces spontaneous facial expressions.

\section{Recovery of tool use and imitation versus recovery of gestures}

Actual tool use is the easiest task and pantomime of tool use is the most difficult task to perform for people with focal left hemisphere lesions (see Baumard et al., 2014). Furthermore, skills of imitation and real tool use or skills of ADL functions has shown to recover better than skills of pantomime (see studies by Stamenova et al., 2011; Donkervoort et al., 2006; Mimura et al., 1996). Daily practice with tool use in everyday life (e.g. using a spoon or a komb) may play a role in better recovery (e.g. Donkervoort et al., 2006). Nevertheless, the skills of a real tool use and pantomiming differ in their purposes, as pantomime conveys linguistic messages (e.g. Goldenberg, 2013) while imitation or tool use do not have this meaning.

A correlation has been proposed between a dominance of language area of the brain and praxis of an arm (Meador et al., 1999) and between deficits in pantomiming and linguistic skills (Borod et.al., 1989; Goldenberg \& Randerath, 2015; Weiss et al., 2016). For example, Weiss et al. (2016) revealed that deficits in pantomiming and imitation of meaningful gestures were correlated to lesions in Broca's area (in the left frontal area), which is widely believed to have a central role in speech output. In contrast, imitation of meaningless gestures in this study did not show a clear correlation to Broca's area. Furthermore, apraxia and aphasia have been shown to have a distinctive neuroanatomical path (e.g. Patiral et al., 2017; Weiss et al., 2016) and recovery of apraxia and aphasia seem not to correlate (see studies by Basso et al., 2000; Mimura et al., 1996; Schnider et al., 
1991). Based on linguistic demands of gesturing, it can be expected, that performance of imitation or tool use and tasks of pantomime in apraxia tests would not ease at the same pace. Finally, based on linguistic demands of gesturing, it would be reasonable to assume, that recovery of aphasia would have an effect on recovery of gestural apraxia. However, the reviewed literature provided no evidence of this, and the issue seems to be an unstudied question.

The notion that gestural apraxia may have poor recovery is not encouraging for people with a severe apraxic-aphasic disorder, considering that embodied actions should be one method to use for compensating absent speech. Stamenova et al. (2011) examined long-term recovery of pantomiming by verbal command that seemed to no longer show significant recovery after 3 months post-stroke. In contrast, Mimura et al. (1997) still noted a significant improvement in pantomiming tasks after a mean time of 4.5 months post-stroke. However, as the time to the next examination was about 6.5 years, it is not known whether there was some recovery throughout this period or if it was limited in time. Ultimately, any valid conclusions about long-term recovery of pantomime skills in apraxia cannot be made based on the limited amount of studies.

In addition to gestures, clinical experience (by the authors) has shown that people with a severe apraxic-aphasic disorder often have problems in writing or drawing. In apraxic agraphia, writing is described as effortful and slow, with unclear or even unrecognizable letter forms (Otsuki, Soma, Arai, Otsuka \& Tsuji, 1999; O’Reilly 2016). Apraxic drawing, instead, refers to difficulty in drawing shapes and objects without problems in understanding, perception, or motor abilities (Chechlacz, Novick, Rotshtein, Bickerton, Humphreys \& Demeyere, 2015). Within the articles retrieved in this search, only the case study by Schnider et al. (1991) included observations on writing and drawing. As apraxia in severe communication disorders co-occur with aphasia, writing problems most likely involve linguistic problems along with possible motor problems of pen (tool) use. Nevertheless, when planning therapy, it is important to consider that apraxic writing problems may be hidden under aphasia (also Krishnan, Rao \& Rajashekar, 2009). 


\section{Imitation versus pantomime as an evaluation method}

Three of the analysed studies (Donkervoort et al., 2006; Basso et al., 2000; and Basso et al., 1987) used only imitation tasks to measure the progress of limb and oral apraxia. As imitation does not pose clear linguistic demands, imitation is considered a valid means of assessing pure limb apraxia (e.g. Vanbellingen \& Bohlhalter, 2011; Niessen, Fink \& Weiss, 2014). However, imitation, due to its non-communicative purpose, cannot be considered as a valid means to assess gestural apraxia. Further, imitation and pantomime after verbal command have been proposed to involve distinct cognitive processing. Defective imitation and defective tool use are connected more to lesions in the parietal area, while defective pantomiming is mainly connected to lesions in the left temporal and inferior frontal areas (see review by Goldenberg, 2017).

Tasks of pantomiming after verbal command, as an examination method of gestural communication, may be problematic in a person with a severe apraxic-aphasic disorder. Examination in clinical settings involve an inherent problem, namely that the clearest symptoms of apraxia appear, by definition, in situations where the person should act voluntarily after a command from another person (e.g. Rothi \& Heilman, 1997; Goldenberg, 2013; Wertz et al., 1991; Patiral et al., 2017; Rose \& Douglas, 2003). Speech and action have been noted to flow more easily in situations where the need for verbal expression or gestural communication has been triggered by the person oneself (e.g. Patiral et al., 2017; Rose \& Douglas, 2003). Instead of clinical settings, gestural training implemented in natural situations has therefore been encouraged (see Vanbellingen \& Bohlhalter, 2011, Rose \& Douglas, 20003). Consistent with this, the observation of the communicative skills of a person with a very severe apraxic-aphasic disorder should happen in as natural situations as possible. Yet, the lower level of control in the test environment needs to be considered in examination, which will introduce challenges in the comparability of scores.

Finally, it is known, that a person with limb apraxia may perform correct pantomimes with a real tool in hand, but not without a tool (e.g. Wada, Nakagawa, Nishikawa, Aso, Inokawa, Kashiwagi, Tanabe \& Takeda, 1999). In their study, the ability of patients to perform 
comprehensive pantomimes increased significantly when they were able to hold a stick in hand. This is an interesting finding, which may have significance in practice.

\section{Spontaneous recovery versus rehabilitation}

In practice it is often impossible to evaluate to what extent the recovery is spontaneous and how much is influenced by rehabilitation. The aim of the long-term follow-up studies presented here was primarily to follow the spontaneous recovery of apraxia even though some participants were reported to receive rehabilitation. The influence of therapy thus cannot be excluded. In the study by Polanowska and Pietrzyk-Krawczyk (2016), the participant received intensive speech therapy within the first month post-stroke; the best recovery of AOS also occurred during the first 3 months. Mimura et al. (1997) mentioned that none of the participants had received speech therapy after 1 year post-stroke. The study showed significant recovery in all apraxia tasks at follow up. However, as the first examination was at a mean of 4.5 months and the second at a mean of nearly 7 years post-stroke, the influence of the therapy cannot be excluded. The study by Donkervoort et al. (2006) indicated recovery of ADL tasks during a 5-month follow-up period; participants received some occupational therapy during that time. In the study by Basso et al. (2000), the significant recovery in apraxia tasks occurred between a mean of 1.6 to 9.4 months post-onset and participants in this study received rehabilitation at least until a mean of 9.4 post onset. None of these studies described the rehabilitation programs.

Deficiency of performing gestures is mostly a permanent symptom in limb apraxia. The main findings in treatment studies of gesturing apraxia indicate that rehabilitation, when intensive and specific, is effective for trained material but without clear generalisation to untrained material (Daumuller \& Goldenberg, 2010; Vanbellingen \& Bohlhalter, 2011; Shimizu \& Tanemura, 2017). Nevertheless, some improvement in untrained gestures has been reported (see Smania, Girardi, Domenicali, Lora \& Aglioti, 2000). Various rehabilitation studies of AOS have also shown that treatment is effective to trained vocabulary (Ballard et al., 2015). 


\section{Limitations of the review}

Although the initial search produced 850 articles, it is possible that the search did not cover all relevant studies on the subject. Although the reference lists of the retrieved studies were reviewed and experts were contacted for more information, only seven studies were included in the final review. Only studies that were published in English were included, which limits the generalizability of the findings on recovery processes in other language groups. An additional limitation is related to the search keywords; the focal keyword used in this study was apraxia, not aphasia. As aphasia and apraxia often co-occur (e.g. Weiss et al., 2016; Etcharry-Bouyx et al., 2017), studies reporting a long-term follow-up of aphasia may involve people with a severe apraxic-aphasic syndrome without assessing or mentioning apraxia. These studies were thus not included in this search. Nevertheless, as scientific research on the long-term changes of aphasia is also very limited (e.g. Klippi \& Helasvuo, 2011), this probably would not have offered substantial knowledge to the subject of changes of apraxic behaviour in communication disorders.

\section{Conclusion}

Scientific research on the long-term recovery from apraxia in severe apraxic-aphasic disorder is limited. One reason for this may be that, apart from AOS, other types of apraxic behaviour have been viewed more as a functional problem in ADL rather than a disturbance of communication. Apraxia of speech lacks follow-up, probably because of its co-occurrence with aphasia and its linguistic symptoms. There are a few long-term follow-up group studies of limb apraxia and oral apraxia in left hemisphere strokes, which measured changes of skills in gesturing, oral (or facial) movements, or use of tools. However, these studies did not discuss limb and oral apraxia as a problem of communication even though some have observed the course of language skills alongside apraxia. In these cases, the studies may have just assumed that recovery from apraxia and aphasia are not related. Some studies also cannot be used to evaluate recovery of gesturing as a means of 
communication, as they used tasks of imitation to measure the changes and imitation is not a comparable skill with communicative gesturing.

The purpose of this review was to determine whether long-term follow-up studies would provide information on recovery of apraxic behaviour in people with left hemisphere stroke with a severe apraxic-aphasic disorder. The major disability in this disorder is a very limited or absent speech output and the inability to efficiently compensate speech with other communicative methods. However, no follow up studies were found that would have discussed apraxia from a communicative point of view. Clinically experienced speech and language therapists find that the communication aids of a person with a severe apraxic-aphasic disorder can consist of voluntary gesturing, writing, drawing, or showing objects from the environment, pictures, or text. To observe the communication skills and its long-term changes of a person with severe apraxic-aphasic disorder, the assessment should include many different communication methods. This knowledge is needed for efficient planning of speech and language therapy.

The author reports no conflict of interest.

\section{References}

Arksey, H. \& O'Malley, L. (2005). Scoping Studies: Towards a Methodological Framework. International Journal of Social Research Methodology, 8(1), 19-32.

Ballard, K.J, Wambaugh, J.L, Duffy, J.R., Layfield, C., Maas, E., Mauszycki, S. \& McNeil, M.R. (2015). Treatment for Acquired Apraxia of Speech: A Systematic Review of Intervention Research Between 2004 and 2012. American Journal of Speech-Language Pathology, 24, 316-337. Baumard, J., Osiurak, F., Lesourd, M. \& Le Gall, D. (2014). Tool use disorders after left brain damage. Frontier in Psychology, 5, 1664-1078. 
Basso, A., Burgio, F., Paulin, M. \& Prandoni, P. (2000). Long-Term Follow-up of Ideomotor Apraxia. Neuropsychological rehabilitation, 10(1), 1-13.

Basso, A., Capitani, E., Della Sala, S., Laiacona, M. \& Spinnler, H. (1987). Recovery from ideomotor apraxia. A study on acute stroke patients. Brain, 110( Pt 3), 747-60.

Borod, J.C, Fitzpatrick, P.M, Helm-Estabrooks, N. \& Goodglass, H. (1989). The Relationship between Limb Apraxia and the Spontaneous Use of Communicative Gesture in Aphasia. Brain and Cognition, 18, 121-131.

Chechlacz, M., Novick, A., Rotshtein, P., Bickerton, W-L., Humphreys, G.W. \& Demeyere, N. (2015). The Neural Substrates of Drawing: A Voxel-based Morphometry Analysis of Constructional, Hierarchical, and Spatial Representation Deficits. Journal of Cognitive Neuroscience, 26(12), 2701-2715.

Daumuller, M. \& Goldenberg, G. (2010). Therapy to improve gestural expression in aphasia: a controlled clinical trial. Clinical Rehabilitation, 24, 55-65.

Donkervoort, M., Dekker, J. \& Deelman, B. (2006). The course of apraxia and ADL functioning in left hemisphere stroke patients treated in rehabilitation centres and nursing homes. Clinical Rehabilitation, 20, 1085-1093.

Elman, R.J., (2005). Social and Life Participation Approaches to Aphasia Intervention. In L. LaPointe (Ed.), Aphasia and Related Neurogenic Language Disorders (pp. 39-50). New York, Stuttgart: T Thieme.

Etcharry-Bouyx, F., Le Gall, D., Jarry, C. \& Osiurak, F. (2017). Gestural apraxia. Revue Neurologique, 173, 430-439.

Foundas, A.L., Macauley, B.L., Raymer,A.M., Maher,L.M., Gonzales-Rothi,L. \& Heilman, K.M. (1995). Ecological implications of limb apraxia: Evidence from mealtime behaviour. Journal of the International Neuropsychological Society, 1, 62-66. 
Foundas, A.L., Raymer,A.M., Maher,L.M., Gonzales-Rothi,L. \& Heilman, K.M. (1993). Recovery in ideomotor apraxia. Journal of Clinical Experimental Neuropsychology, 14, 44.

Gianquinto, S. Buzzelli, S. Di Francesco, L., Lottarini, A., Montenero. P., Tonin. P. \& Nolfe, G. (1999). On the prognosis of outcome after stroke. Acta Neurologica Scandanavica, 100, 202-208. Goldenberg, G. (2013). Apraxia - The cognitive side of motor control. Oxford, UK: Oxford University Press.

Goldenberg, G. (2017). Facets of Pantomime. Journal of the International Neuropsychological Society, 23, 121-127.

Goldenberg, G. \& Randerath, J. (2015). Shared neural substrates of apraxia and aphasia. Neuropsychologia, 75, 40-49.

Graff-Radford, J., Jones, D.T., Strand, E.A., Rabinstein, A.A., Duffy, J.R. \& Josephs, K.A. (2014). The neuroanatomy of pure apraxia of speech in stroke. Brain \& Language, 129, 43-36.

Hogrefe, K., Ziegler, W., Weidinger, N. \& Goldenberg, G. (2011). Non-verbal communication in sever aphasia: Influence of aphasia, apraxia, or semantic processing? Cortex, 48, 952-962.

Klippi, A. \& Helasvuo, M.-L. (2011). Changes in agrammatic conversational speech over a 20 year period - from single word turns to grammatical constructions. Journal of Interactional Research in Communication Disorders, 2(1), 29-59.

Krishnan, G., Rao, S.N. \& Rajashekar, B. (2009). Apraxic agraphia: An insight into the writing disturbances of posterior aphasias. Annals of Indian Academy of Neurology, 12(2), 120-123. LaPointe, L. (2005). Aphasia and Related Neurogenic Language Disorders. New York, Stuttgart: T Thieme.

Meador, K.J., Loring, D.W., Lee, K., Hughes, M., Lee, G., Nichols, M. \& Heilman, K.M. (1999). Cerebral lateralization: Relationship of language and ideomotor praxis. Neurology, 53(9), 20282031. 
Mimura, M., Fitzpatrick, P.M., Albert, M.L. (1996). Long-term recovery from ideomotor apraxia. Neuropsychiatry, Neuropsychology and Behavioral Neurology, 9(2), 127-132.

Moher, D., Liberati, A., Tetzlaff, J., Altman, D.G. \& the PRISMA Group. (2009). Preferred Reporting Items for Systematic Reviews and Meta-Analyses: The PRISMA Statement. Annals of Internal Medicine, 151(4).

Niessen, E., Fink, G.R. \& Weiss, P.H. (2014). Apraxia, pantomime and the parietal cortex. NeuroImage Clinical, 5, 42-52.

O’Reilly, A. (2016). Assessment and management of apraxic agraphia: applying principles from the management of apraxia of speech and the principles of motor learning. Aphasiology, 30(4), 414434.

Otsuki, M., Soma, Y., Arai, T., Otsuka, A. \& Tsuji, S. (1999). Pure apraxic agraphia with abnormal writing stroke sequences: report of a Japanese patient with a left superior parietal haemorrhage. $J$ Neurol Neurosurg Psychiatry, 66, 233-237.

Patiral, R., Ciniglia, L.,Calvert, T. \& Altschuler, E. (2017). Pure apraxia of speech in premotor cortex. Polish Journal of Neurology and Neurosurgery, 51, 519-524.

Polanowska, K.E., \& Pietrzyk-Krawczyk, I. (2016). Post-stroke pure apraxia of speech - A rare experience. Polish Journal of Neurology and Neurosurgery, 50, 497-503.

Rose, M. \& Douglas, J.M. (2003). Limb apraxia, pantomime, and lexical gesture in aphasic speakers: Preliminary findings. Aphasiology, 17(5), 453-464.

Rothi, L.J. \& Heilman, K.M. (1997). Apraxia-The Neuropsychology of Action. London, UK: Psychology Press.

Saeki, S., Ogata, H., Okubo, T., Takahashi, K. \& Hoshuyama, T. (1995). Return to work after stroke: A follow-up study. Stroke, 26, 399-401.

Schnider, A., Landis, T. \& Rösler, H. (1991). Ideomotor Apraxia in Left Thalamic Hemorraghe: Discrepancy between Clinical Course and SPECT. Behavioral Neurology, 4, 15-24. 
Shimizu, D. \& Tanemura, R. (2017). Crossover learning of gestures in two ideomotor apraxia patients: A single case experimental design study. Neuropsychological Rehabilitation, 27(4), 563580.

Smania, N., Girardi, F., Domenicali, C., Lora, E. \& Aglioti, S. (2000). The Rehabilitation of Limb Apraxia: A Study in Left-Brain-Damaged Patients. American Congress of Rehabilitation Medicine and the American Academy of Physical Medicine and Rehabilitation, 81, 379-88.

Stamenova, V., Black, S.E. \& Roy, E.A. (2011). A model-based approach to long-term recovery of limb apraxia after stroke. Journal of Clinical and Experimental Neuropsychology, 33(9), 954-971. Trupe, L.A., Varma, D., Gomez, Y., Race, D., Leigh, R., Hillis, A. \& Gottesman, R. (2013). Chronic Apraxia of Speech and Broca's Area. Stroke, 44, 740-744.

Vanbellingen, T. \& Bohlhalter, S. (2011). Limb apraxia: a disorder of gesturing and object use. In O. Godefroy (Ed.), The Behavioral and Cognitive Neurology of Stroke (pp. 55-64). New York: Cambridge University Press.

Wada, Y., Nakagawa, Y., Nishikawa, T., Aso, N., Inokawa, M., Kashiwagi, A., Tanabe, H. \& Takeda, M. (1999). Role of somatosensory feedback from tools in realizing movement by patients with ideomotor apraxia. European Neurology, 41, 73-78.

Weiss, P, Ubben, S., Kaesberg, S., Kalbe, E., Kessler, J., Liebig, T. \& Fink, G. (2016). Where language meets meaningful action: a combined behaviour and lesion analysis of aphasia and apraxia. Brain Struct Funct, 221, 563-576.

Wertz, R., LaPointe, L. \& Rosenbek, J. (1991). Apraxia of Speech in Adults. The disorder and its Management. San Diego, California: Singular Publishing Group.

Whiteside, S.P, Dyson. L., Cowell, P.E. \& Varley, R.A. (2015). The Relationship Between Apraxia of Speech and Oral Apraxia: Association or Dissociation? Archives of Clinical Neuropsychology, 30(7), 670-682. 
805 references (after removing duplicates) identified through database search.

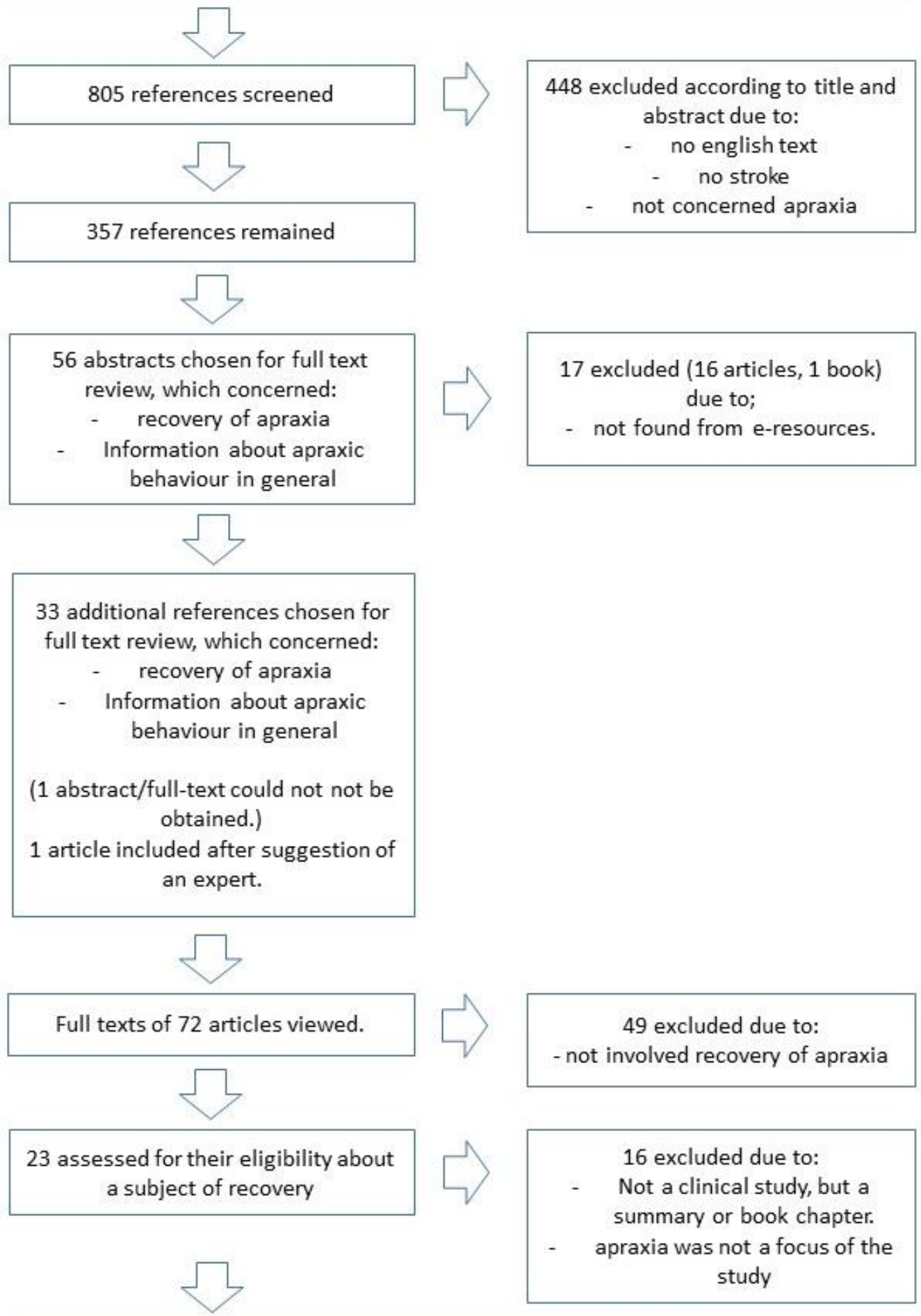

Seven studies of recovery of apraxia with left hemispheric stroke 


\begin{tabular}{|c|c|c|c|c|c|c|c|c|}
\hline Study & $\begin{array}{l}\text { Aim of the } \\
\text { study }\end{array}$ & $\begin{array}{l}\text { Number } \\
\text { of } \\
\text { particip } \\
\text { ants }\end{array}$ & Diagnoses & $\begin{array}{l}\text { time of } \\
\text { post- } \\
\text { onset }\end{array}$ & $\begin{array}{l}\text { Inclusion criteria } \\
\text { regarding } \\
\text { apraxia (and } \\
\text { aphasia) }\end{array}$ & $\begin{array}{l}\text { Assessment of } \\
\text { apraxia, (and aphasia } \\
\text { if performed) }\end{array}$ & $\begin{array}{l}\text { Time of follow- } \\
\text { up post-stroke }\end{array}$ & Main results \\
\hline $\begin{array}{l}\text { Polanowska, K. \& } \\
\text { Pietrzyk- } \\
\text { Krawczyk, I. } \\
\text { (2016). Post- } \\
\text { stroke pure } \\
\text { apraxia of speech } \\
\text { - A rare } \\
\text { experience. Polish } \\
\text { Journal of } \\
\text { Neurology and } \\
\text { Neurosurgery 50, } \\
\text { 497-503. }\end{array}$ & $\begin{array}{l}\text { To prescribe } \\
\text { symptoms of } \\
\text { acquired apraxia } \\
\text { of speech and to } \\
\text { show how } \\
\text { characteristics } \\
\text { of speech } \\
\text { changes over } \\
\text { time. }\end{array}$ & $\begin{array}{l}1 \text { male, } \\
49 \text { years } \\
\text { right- } \\
\text { handed }\end{array}$ & $\begin{array}{l}\text { left } \\
\text { ischaemic } \\
\text { CVA } \\
\text { apraxia of } \\
\text { speech }\end{array}$ & 1 week & $\begin{array}{l}\text { Minimum speech } \\
\text { output. Ability to } \\
\text { communicate by } \\
\text { writing and } \\
\text { correct non-verbal } \\
\text { yes or no answers. } \\
\text { Good auditive and } \\
\text { written verbal } \\
\text { comprehension. }\end{array}$ & $\begin{array}{l}\text { Frenchay dysarthria } \\
\text { assessment - FDA } 2 \\
\text { short version of Boston } \\
\text { diagnostic aphasia } \\
\text { examination - BDAE } \\
\text { Apraxia battery for } \\
\text { adults - ABA-2 }\end{array}$ & $\begin{array}{l}1 \text { week, } 1 \text { month, } \\
3 \text { months, and } 1 \\
\text { year }\end{array}$ & $\begin{array}{l}\text { Speech articulation } \\
\text { improved to nearly } \\
\text { normal with some } \\
\text { dysprosody within } 3 \\
\text { months. } \\
\text { Some dysprosody left } \\
\text { after } 1 \text { year. }\end{array}$ \\
\hline $\begin{array}{l}\text { Schnider, A., } \\
\text { Landis, T. \& } \\
\text { Rösler, H. (1991). } \\
\text { Ideomotor } \\
\text { Apraxia in Left } \\
\text { Thalamic } \\
\text { Hemorraghe: } \\
\text { Discrepancy } \\
\text { between Clinical } \\
\text { Course and } \\
\text { SPECT. } \\
\text { Behavioral } \\
\text { Neurology, 4, 15- } \\
24 .\end{array}$ & $\begin{array}{l}\text { To view the } \\
\text { parallel of } \\
\text { recovery from } \\
\text { ideomotor } \\
\text { apraxia to blood } \\
\text { flow in the brain } \\
\text { as measured by } \\
\text { SPECT. } \\
\text { (This table notes } \\
\text { only the course } \\
\text { of recovery of } \\
\text { speech and } \\
\text { apraxia } \\
\text { observed in the } \\
\text { study.) }\end{array}$ & $\begin{array}{l}1 \\
\text { woman, } \\
60 \text { years } \\
\text { right- } \\
\text { handed }\end{array}$ & $\begin{array}{l}\text { left thalamus } \\
\text { haemorrhage } \\
\text { Ideomotor } \\
\text { and oral } \\
\text { apraxia }\end{array}$ & 3 days & $\begin{array}{l}\text { Defective } \\
\text { gesturing and oral } \\
\text { movements. }\end{array}$ & $\begin{array}{l}\text { Apraxia score used in } \\
\text { the study; meaningful } \\
\text { gestures and oral } \\
\text { movements performed } \\
\text { after verbal commands } \\
\text { and imitation. } \\
\text { Observation of speech } \\
\text { with aphasic } \\
\text { paraphasia (tasks not } \\
\text { mentioned). } \\
\text { Observation of writing } \\
\text { and drawing skills } \\
\text { (tasks not mentioned } \\
\text { known). }\end{array}$ & $\begin{array}{l}3,5,9,11,12,16, \\
24,97, \text { and } 157 \\
\text { days. }\end{array}$ & $\begin{array}{l}\text { Patient could speak } \\
\text { sentences after } 2 \text { weeks. } \\
\text { Speech normalized } \\
\text { within } 5 \text { months. } \\
\text { Ideomotor and oral } \\
\text { apraxia recovered almost } \\
\text { entirely in } 3 \text { weeks. After } \\
5 \text { months patient still } \\
\text { used body parts as } \\
\text { objects. } \\
\text { After } 2 \text { weeks patient } \\
\text { could draw and write } \\
\text { with a model. Writing } \\
\text { skills normalized within } \\
5 \text { months (long-term } \\
\text { recovery of drawing not } \\
\text { mentioned). }\end{array}$ \\
\hline
\end{tabular}




\begin{tabular}{|c|c|c|c|c|c|c|c|c|}
\hline $\begin{array}{l}\text { Mimura, M., } \\
\text { Fitzpatrick, P.M., } \\
\text { Albert, M.L. } \\
\text { (1996). Long- } \\
\text { term recovery } \\
\text { from ideomotor } \\
\text { apraxia. } \\
\text { Neuropsychiatry, } \\
\text { Neuropsychology } \\
\text { and Behavioral } \\
\text { Neurology } 9(2), \\
\text { pp. 127-132. }\end{array}$ & $\begin{array}{l}\text { To follow } \\
\text { recovery of limb } \\
\text { apraxia (LA) } \\
\text { and buccofacial } \\
\text { apraxia (BFA). } \\
\text { To examine if } \\
\text { recovery of } \\
\text { aphasia and } \\
\text { apraxia are } \\
\text { related. }\end{array}$ & $\begin{array}{l}15 \\
14 \text { male } \\
1 \text { female } \\
\text { right- } \\
\text { handed }\end{array}$ & $\begin{array}{l}\text { Left CVA } \\
\text { Limb } \\
\text { apraxia and } \\
\text { buccofacial } \\
\text { apraxia, } \\
\text { aphasia }\end{array}$ & $\begin{array}{l}4.5 \\
\text { months } \\
\text { (mean) }\end{array}$ & $\begin{array}{l}\text { Mild to severe } \\
\text { apraxia. } \\
\text { Fluent, nonfluent, } \\
\text { or mixed aphasia. }\end{array}$ & $\begin{array}{l}\text { Boston Apraxia } \\
\text { Examination: } \\
\text { Buccofacial and } \\
\text { transitive and } \\
\text { intransitive movements } \\
\text { of an arm by verbal } \\
\text { command and } \\
\text { imitation. } \\
\text { Boston Aphasia } \\
\text { Examination: } \\
\text { Naming, repetition, } \\
\text { phrase length, single- } \\
\text { word auditory } \\
\text { comprehension, } \\
\text { aphasia severity. }\end{array}$ & $\begin{array}{l}4.5 \text { months } \\
\text { (mean) } \\
\text { and } \\
\begin{array}{l}81.6 \text { months } \\
\text { (mean) }\end{array}\end{array}$ & $\begin{array}{l}\text { More initially severe LA } \\
\text { predicted more severe } \\
\text { LA at the end. And more } \\
\text { initially severe BFA in } \\
\text { patients with nonfluent } \\
\text { aphasia. } \\
\text { Significant correlation } \\
\text { between recovery from } \\
\text { BFA in nonfluent } \\
\text { aphasia, but not in fluent } \\
\text { aphasia. } \\
\text { No significant correlation } \\
\text { between recovery from } \\
\text { LA and aphasia type. } \\
\text { No correlation between } \\
\text { recovery from apraxia } \\
\text { and aphasia when } \\
\text { analysing nonfluent and } \\
\text { fluent aphasics together } \\
\text { in group level. } \\
\text { Significant, "striking" } \\
\text { recovery from limb and } \\
\text { buccofacial apraxia } \\
\text { overall. } \\
\text { Better recovery in } \\
\text { imitation comparing } \\
\text { performance by verbal } \\
\text { command. } \\
\text { At follow up, } 6 \text { still had } \\
\text { limb apraxia and } 9 \text { had } \\
\text { buccofacial apraxia. }\end{array}$ \\
\hline
\end{tabular}




\begin{tabular}{|c|c|c|c|c|c|c|c|c|}
\hline $\begin{array}{l}\text { Stamenova, V., } \\
\text { Black, S. \& Roy, } \\
\text { E. (2011). A } \\
\text { model-based } \\
\text { approach to long- } \\
\text { term recovery of } \\
\text { limb apraxia after } \\
\text { stroke. Journal of } \\
\text { Clinical and } \\
\text { Experimental } \\
\text { Neuropsychology, } \\
\text { 33:9, 954-971. }\end{array}$ & $\begin{array}{l}\text { To determine if } \\
\text { patients show } \\
\text { spontaneous } \\
\text { improvement in } \\
\text { (limb) apraxia } \\
\text { tasks in acute- } \\
\text { subacute and } \\
\text { chronic stage } \\
\text { post-onset. }\end{array}$ & $\begin{array}{l}37 \\
22 \text { left } \\
\text { CVA } \\
15 \text { right } \\
\text { CVA } \\
\text { (4 left- } \\
\text { handed) }\end{array}$ & $\begin{array}{l}\text { left or right } \\
\text { CVA }\end{array}$ & $\begin{array}{l}13 \text { in } \\
\text { acute- } \\
\text { subacute } \\
\text { stage } \\
\text { (under } 3 \\
\text { months, } \\
\text { mean } 24 \\
\text { days) } \\
\text { and } \\
21 \text { in } \\
\text { chronic } \\
\text { stage } \\
\text { (over } 3 \\
\text { months, } \\
\text { mean } 37 \\
\text { months) } \\
27 \\
\text { subjects } \\
\text { as } \\
\text { controls }\end{array}$ & Not mentioned & $\begin{array}{l}\text { Action identification, } \\
\text { tool naming by action, } \\
\text { tool naming, } \\
\text { tool identification, } \\
\text { pantomime by verbal } \\
\text { command, } \\
\text { pantomime by picture, } \\
\text { tool use, } \\
\text { delayed imitation, } \\
\text { concurrent imitation } \\
\text { Assessment times } \\
\text { varied among patients: } \\
21 \text { assessed twice, } 9 \\
\text { three times, } 2 \text { four } \\
\text { times, } 5 \text { five times }\end{array}$ & $\begin{array}{l}\text { Varied across } \\
\text { participants from } \\
83 \text { days } \\
\text { to } 117 \text { months } \\
\text { (mean } 31.5 \pm 28 \\
\text { months). }\end{array}$ & $\begin{array}{l}\text { Poorer recovery rate in } \\
\text { chronic stage than in } \\
\text { acute stage only in } \\
\text { pantomime and } \\
\text { pantomime by picture } \\
\text { tasks. } \\
\text { Recovery in tool use task } \\
\text { when holding real tool in } \\
\text { hand showed the best } \\
\text { recovery both in acute } \\
\text { and chronic stage. } \\
\text { Similar recovery in } \\
\text { imitation both in acute } \\
\text { and chronic stage. } \\
\text { Scores in apraxia tasks } \\
\text { improved more in } \\
\text { patients with more severe } \\
\text { apraxia. }\end{array}$ \\
\hline $\begin{array}{l}\text { Basso, A., Burgio, } \\
\text { F., Paulin, M. \& } \\
\text { Prandoni, P. } \\
\text { (2000). Long- } \\
\text { Term Follow-up } \\
\text { of Ideomotor } \\
\text { Apraxia. } \\
\text { Neuropsychologic } \\
\text { al rehabilitation } \\
10 \text { (1), 1-13. }\end{array}$ & $\begin{array}{l}\text { To determine if } \\
\text { ability of } \\
\text { imitating } \\
\text { gestures and } \\
\text { oral movements } \\
\text { changes in } \\
\text { follow-up in } \\
\text { patients with } \\
\text { apraxia. } \\
\text { To determine if } \\
\text { apraxia reflects } \\
\text { the same } \\
\text { recovery rate } \\
\text { with other } \\
\text { neuropsychologi } \\
\text { cal deficits. }\end{array}$ & $\begin{array}{l}4 \\
\\
23 \text { male } \\
21 \\
\text { female } \\
\text { right- } \\
\text { handed }\end{array}$ & $\begin{array}{l}\text { left CVA } \\
\text { ideomotor } \\
\text { apraxia }\end{array}$ & $\begin{array}{l}1-3 \\
\text { months }\end{array}$ & $\begin{array}{l}\text { Max } 49 \text { scores in } \\
\text { first gesture } \\
\text { imitation test }\end{array}$ & $\begin{array}{l}\text { Ideomotor apraxia } \\
\text { (IMA) test: To imitate } \\
24 \text { meaningful or } \\
\text { meaningless gestures } \\
\text { Oral apraxia (OA) test: } \\
\text { To imitate } 10 \text { different } \\
\text { buccofacial } \\
\text { movements. } \\
\text { Token test: to assess } \\
\text { auditory language } \\
\text { comprehension. } \\
\text { Raven's coloured } \\
\text { progressive matrices: }\end{array}$ & $\begin{array}{l}\text { 1-3 months post- } \\
\text { onset (mean 1.6) } \\
\text { At least } 4 \text { months } \\
\text { after first } \\
\text { examination } \\
\text { (mean 9.4) } \\
\text { At least } 6 \text { months } \\
\text { after second } \\
\text { examination } \\
\text { (minimum } 18 \\
\text { months post- } \\
\text { onset, mean 27.9) }\end{array}$ & $\begin{array}{l}\text { Main recovery in IMA } \\
\text { and OA during the first } \\
\text { months post-stroke. } \\
\text { Significant recovery with } \\
\text { all measured tasks } \\
\text { between the first and the } \\
\text { second examination. } \\
\text { 26/44 showed no signs of } \\
\text { IMA in second } \\
\text { examination. } \\
\text { No significant recovery } \\
\text { in OA and IMA after } \\
\text { second examination. }\end{array}$ \\
\hline
\end{tabular}




\begin{tabular}{|c|c|c|c|c|c|c|c|c|}
\hline & $\begin{array}{l}\text { To determine if } \\
\text { recovery differs } \\
\text { if the lesion site } \\
\text { is anterior or } \\
\text { posterior. }\end{array}$ & & & & & $\begin{array}{l}\text { To assess non-verbal } \\
\text { thinking. }\end{array}$ & & $\begin{array}{l}\text { Significant recovery in } \\
\text { Token test and Raven's } \\
\text { at third examination. } \\
\text { More severe ideomotor } \\
\text { apraxia in anterior } \\
\text { lesions than in posterior } \\
\text { lesions, but no significant } \\
\text { differences in recovery } \\
\text { rates. }\end{array}$ \\
\hline $\begin{array}{l}\text { Basso, A., } \\
\text { Capitani, E., } \\
\text { Della Sala, S., } \\
\text { Laiacona, M. \& } \\
\text { Spinnler, H. } \\
\text { (1987). Recovery } \\
\text { from ideomotor } \\
\text { apraxia. A study } \\
\text { on acute stroke } \\
\text { patients. Brain. } \\
110(\text { Pt 3):747-60. }\end{array}$ & $\begin{array}{l}\text { To view course } \\
\text { of ideomotor } \\
\text { apraxia and to } \\
\text { determine if } \\
\text { another lesion in } \\
\text { right } \\
\text { hemisphere } \\
\text { effects recovery. }\end{array}$ & $\begin{array}{l}26 \\
19 \text { male } \\
7 \text { female } \\
+8 \\
\text { (gender } \\
\text { not } \\
\text { mentione } \\
\text { d) }\end{array}$ & $\begin{array}{l}26 \text { with left } \\
\text { CVA and } \\
\text { ideomotor } \\
\text { apraxia. } \\
8 \text { with } \\
\text { bilateral } \\
\text { lesions and } \\
\text { ideomotor } \\
\text { apraxia. }\end{array}$ & $\begin{array}{l}15-30 \\
\text { days with } \\
\text { left CVA } \\
\text { participa } \\
\text { nts. } \\
\text { Time } \\
\text { post- } \\
\text { stroke } \\
\text { not } \\
\text { mentione } \\
\text { d in } \\
\text { bilateral } \\
\text { group. }\end{array}$ & $\begin{array}{l}\text { Less than } 53 / 72 \text { in } \\
24 \text {-item test. } \\
\text { Less than } 16 / 20 \text { in } \\
10 \text {-item test. }\end{array}$ & $\begin{array}{l}\text { Ideomotor apraxia, 24- } \\
\text { item test: To imitate } \\
\text { meaningful and } \\
\text { meaningless } \\
\text { movements and single } \\
\text { and sequential } \\
\text { movements of an arm, } \\
\text { hand, and fingers. } \\
\text { Oral apraxia, 10-item } \\
\text { test: To imitate } \\
\text { movements of } \\
\text { buccofacial } \\
\text { musculature. } \\
\text { Aphasia test: Token } \\
\text { test and Standard } \\
\text { Language examination } \\
\text { Raven's coloured } \\
\text { progressive matrices } \\
\text { (The study was not } \\
\text { clear in whether tests } \\
\text { performed on all } \\
\text { participants) }\end{array}$ & $\begin{array}{l}15-30 \text { days } \\
\text { and } \\
\text { at least } 5 \text { months } \\
\text { and } 11 \\
\text { participants } \\
\text { "some months" } \\
\text { after latest } \\
\text { examination }\end{array}$ & $\begin{array}{l}\text { All recovered } \\
\text { significantly in apraxia } \\
\text { tasks by } 5 \text { months post- } \\
\text { stroke. } \\
5 \text { were still apraxic at } \\
\text { third examination. } \\
\text { Ideomotor apraxia } \\
\text { correlates more with oral } \\
\text { apraxia than other tests. } \\
\text { Another lesion in the } \\
\text { right hemisphere did not } \\
\text { affect recovery of } \\
\text { ideomotor apraxia. } \\
\text { Better recovery of } \\
\text { apraxia in anterior than } \\
\text { posterior lesions. } \\
\text { (25/26 with left-sided } \\
\text { lesions also had aphasia } \\
\text { at first examination, but } \\
\text { study did not discuss } \\
\text { course of aphasia) }\end{array}$ \\
\hline $\begin{array}{l}\text { Donkervoort, M., } \\
\text { Dekker, J. \& } \\
\text { Deelman, B. }\end{array}$ & $\begin{array}{l}\text { To determine } \\
\text { the course of } \\
\text { apraxia and how }\end{array}$ & $\begin{array}{l}108 \\
61 \text { male }\end{array}$ & $\begin{array}{l}\text { left CVA: } \\
85 \text { infarct }\end{array}$ & $\begin{array}{l}4 \text { weeks- } \\
2 \text { years }\end{array}$ & $\begin{array}{l}\text { Inability to carry } \\
\text { out purposeful } \\
\text { activities without }\end{array}$ & $\begin{array}{l}\text { Apraxia test: Ability to } \\
\text { use or mime objects } \\
\text { and imitate gestures }\end{array}$ & At baseline & $\begin{array}{l}\text { Apraxia was persistent } \\
\text { for most participants. }\end{array}$ \\
\hline
\end{tabular}




\begin{tabular}{|c|c|c|c|c|c|c|c|c|}
\hline $\begin{array}{l}\text { (2006). The } \\
\text { course of apraxia } \\
\text { and ADL } \\
\text { functioning in left } \\
\text { hemisphere stroke } \\
\text { patients treated in } \\
\text { rehabilitation } \\
\text { centres and } \\
\text { nursing homes. } \\
\text { Clinical } \\
\text { Rehabilitation; } \\
\text { 20: 1085-1093 }\end{array}$ & $\begin{array}{l}\text { the severity of } \\
\text { apraxia } \\
\text { influences ADL } \\
\text { functioning. }\end{array}$ & $\begin{array}{l}47 \\
\text { female } \\
\text { (92\% } \\
\text { right- } \\
\text { handed) }\end{array}$ & $\begin{array}{l}15 \\
\text { haemorrhage } \\
8 \text { other/not } \\
\text { known } \\
\text { apraxia }\end{array}$ & $\begin{array}{l}\text { (mean } \\
67.6 \\
\text { days) }\end{array}$ & $\begin{array}{l}\text { problems of } \\
\text { motor or sensory } \\
\text { impairments, } \\
\text { motivation or } \\
\text { comprehension } \\
\text { Less than } 87 \\
\text { scores in } \\
\text { neuropsychologic } \\
\text { al apraxia test } \\
\text { used in the study }\end{array}$ & $\begin{array}{l}\text { Motor functioning of } \\
\text { contralateral arm and } \\
\text { leg } \\
\text { Activities of daily } \\
\text { functioning (ADL): } \\
\text { Observation of } \\
\text { personal hygiene, } \\
\text { dressing, preparing } \\
\text { sandwich and hot } \\
\text { chocolate. } \\
\text { Barthel ADL Index }\end{array}$ & $\begin{array}{l}8 \text { weeks after } \\
\text { baseline } \\
5 \text { months after } \\
\text { baseline }\end{array}$ & $\begin{array}{l}\text { Most significant recovery } \\
\text { occurred } 6 \text { months post- } \\
\text { stroke. } \\
\text { Apraxia had negative } \\
\text { influence on ADL scores } \\
\text { in first } 8 \text { weeks. This } \\
\text { influence was no longer } \\
\text { significant at later follow } \\
\text { up. } \\
\text { ADL functioning scores } \\
\text { improved better than } \\
\text { apraxia scores. }\end{array}$ \\
\hline
\end{tabular}


